\title{
https://doi.org/10.52240/1857-2367.2020.2(21).54 \\ COLECŢIA DE CACTUŞI (CACTACEAE JUSS.) ÎN GRĂDINA BOTANICĂ NAŢIONALĂ (INSTITUT) „ALEXANDRU CIUBOTARU”
}

\author{
Valentina ŢIMMBALÎ, Sergiu ROGACICO \\ Grădina Botanică Naţională (I) „Al. Ciubotaru”, \\ Chișinău, Republica Moldova
}

\begin{abstract}
During about 50 years, at the "Al. Ciubotaru" NBGI, the collection of plants of the Cactaceae family has been created and enriched, thus, now, at the end of 2020, it includes 985 taxa, in 141 genera. More than $50 \%$ of the total number of taxa are able to reach the generative phase (flowering), and about 35$40 \%$ produce fruits with seeds. The basic method of propagating cacti is by seeds. Freshly collected seeds germinate over 3 to 11 days, but the seedlings grow and develop very slowly.
\end{abstract}

Key words: family, subfamily, taxon, species, cacti, collection, mobilization, introduction.

Familia Cactaceae Juss. este una din cele mai mari grupe de plante superioare, ea numără peste 3000 de specii. În serele Grădinii Botanice Naționale (I) “Al. Ciubotaru” este cea mai bine reprezentată - 985 taxoni, din 141 genuri, incadrate în 3 subfamilii [1,2]: Peireskioideae Schum. cu genurile Peireskia Mill. ( 4 taxoni); Rhodocactus Knuth. (1); Opuntioideae Schum. cu genurile Quiabentia Br.\&R.-1; Peireskiopsis Br.\&R.-1; Austrocinldopuntia Backbg. -7; Braziliopuntia Berger (1); Consolea Lem. (2); Corynopuntia Knuth.(1 ); Cylindropuntia Backbg. (2); Grusonia F. Reichb. (2); Opuntia Mill. (52); Tephrocactus Backbg. (1) şi Cereoideae Schum. cu cel mai mare număr de genuri. Din această subfamilie cele mai reprezentative genuri sunt: Mammillaria Haw. ( 208); Rebutia Schum.(30); Rhipsalis Gartn. (33); Astrophytum Lem. (20); Aylostera Speg. (17); Cleistocactus Lem. (17); Copiapoa Britt et Rose (17); Coryphantha Lem. (24); Echinocereus Engelm. (36); Echinofossulocactus Lawrence ( 19); Ferocactus Britt et Rose (21); Gymnocalicium Pfeiff. (40); Lobivia Britt et Rose (34); Neochilenia Backeb. (20); Notocactus Berger (23); Trichocereus Riccob. (14); Turbinicarpus Buxb. et Backeb. (11). Alte genuri sunt reprezentate printr-un număr mai mic de taxoni.

Completarea colecţiei are loc prin mai multe căi: schimb internaţional de seminţe prin intermediul Catalogului de seminţe Index seminum cu diferite organizaţii cu profil botanic din lume, schimb cu colecţionarii de cactuşi şi donaţii.

Perioada de înflorire a cactuşilor este îndelungată, practic pe parcursul întregului an, însă cei mai mulţi taxoni înfloresc primăvara-vara. Pentru a obține seminţe calitative, fructele se recoltează când sunt bine coapte, de obicei din toamnă până în primăvară. Numărul de taxoni care trec în faza generativă (înflorire) variază de la an la an, dar constitue 50-60\% din numărul total. Fructe cu seminţe viabile formează doar 35-40\%.

Metoda optimă de înmulţire a cactuşilor în serele GBN(I) „Al. Ciubotaru” este cea generativă (prin seminţe), dar se practică şi cea vegetativă: prin detaşarea plantelor tinere de la planta-mamă prin sădire în cazul prezenţei sistemului radicular, sau înrădăcinare în substrat când acesta lipseşte.

Colecţia de cactuşi a GBN (I) are o valoare de unicat pentru Republica Moldova şi serveşte ca material demonstrativ pentru procesul instructiv-educaţivl al elevilor, liceenilor, studenţilor şi masteranzilor. 
Teza este realizată în cadrul proiectului „Cercetări privind mobilizarea diversităţii vegetale cu potenţial ornamental pentru conservarea ex-situ"

\section{BIBLIOGRAFIE SELECTIVĂ}

1. Copăcescu S.V.,2001 - Cactuşii Monografie, Editura „Ceres” Bucureşti», 695 p.

2. Backeberg, N. 1979 - Das Kakteenlexicon, Veb Gustav Fischer Verlag Jena, 822 p.

3. Методика фенологических наблюдений в ботанических садах СССР, 1975- Москва, «Наука» 